Supporting Information

\title{
Effectiveness of iron chelator CN128 in mitigating the formation of dopamine oxidation products associated with the progression of Parkinson's disease
}

\author{
Yingying Sun, ${ }^{1}$ A. Ninh Pham, ${ }^{1}$ Robert C. Hider, ${ }^{2}$ Haolin Zheng ${ }^{1}$ and T. David Waite ${ }^{1 *}$ \\ ${ }^{1}$ Water Research Centre and School of Civil and Environmental Engineering, The University of New \\ South Wales, Sydney, NSW 2052, Australia \\ ${ }^{2}$ Institute of Pharmaceutical Science, King's College, London, United Kingdom
}

Keyword: Iron chelator; Dopamine; ROS; Quinone; Iron overload and Parkinson's disease

Re-Submitted

October 2020

ACS Chemical Neuroscience

* Corresponding author. Professor T. David Waite, Tel.: +61 29385 5059, Email:

d.waite@unsw.edu.au 


\section{SI 1 Distribution of DA-bound iron}

The results of thermodynamic equilibrium calculations shown in FIGURE S1A and B indicate that, in the presence of $5 \mu \mathrm{M} \mathrm{Fe}(\mathrm{III})$, the dominant species changes from the bis-complex to the tris-complex when the concentration of DA increases from $50 \mu \mathrm{M}$ DA to $2 \mathrm{mM}$ DA. This result is consistent with the cellular experiments regarding the iron enhanced toxicity of DA shown in FIGURE 2. As shown in FIGURE S1C, an increase in the ratio of the $\mathrm{Fe}^{\mathrm{III}}(\mathrm{DA})_{3}$ and $\mathrm{Fe}^{\mathrm{III}}(\mathrm{DA})_{2}$ is evident when the ratio of DA and iron increases, indicating that the tris-complex between iron and DA may be important when severe leakage of DA occurs at the later stage. 

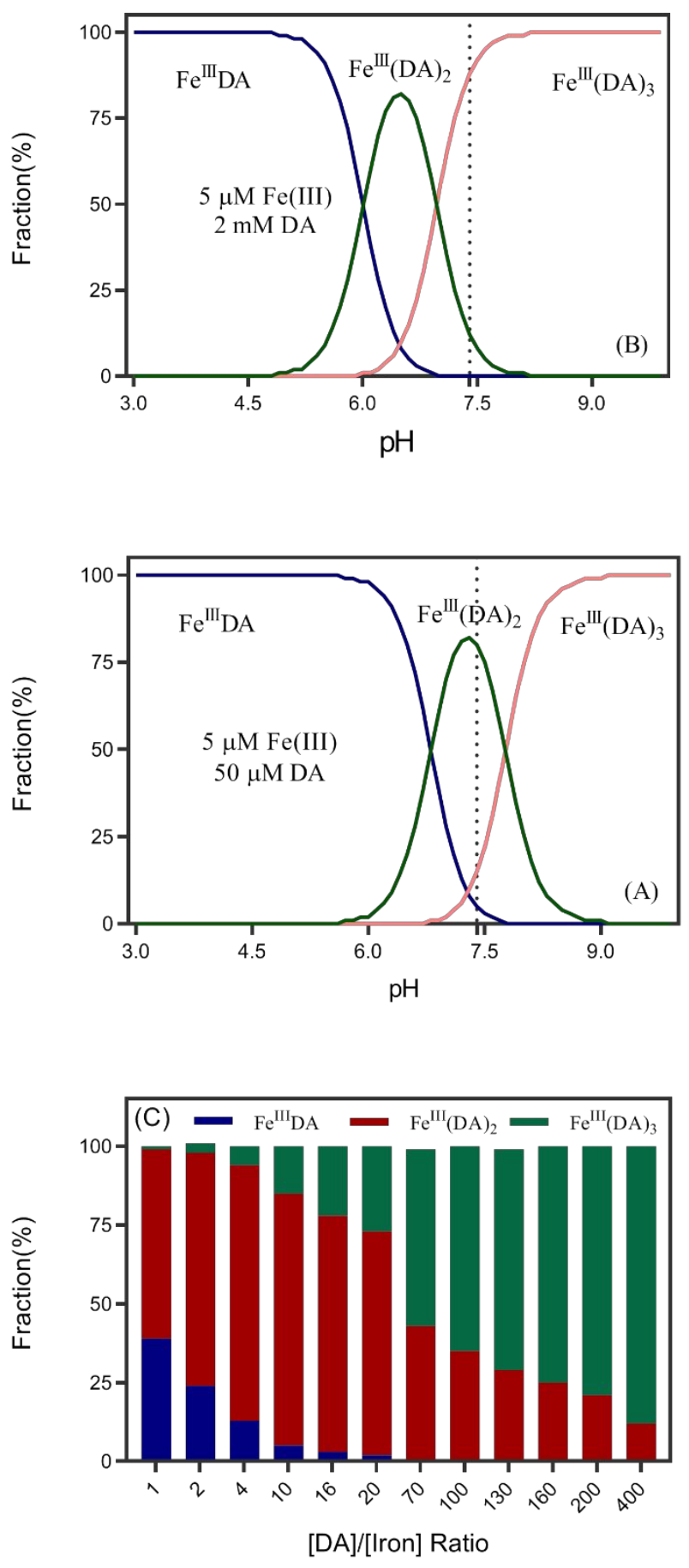

FIGURE S1. Speciation of DA-bound iron in the presence of $50 \mu \mathrm{M}$ DA and $5 \mu \mathrm{M}$ Fe(III) (Panel A), 2 $\mathrm{mM} \mathrm{DA}$ and $5 \mu \mathrm{M} \mathrm{Fe}(\mathrm{III})$ (Panel B) and distribution of DA-bound iron species in the presence of different DA to iron ratio at $\mathrm{pH} 7.4$ (Panel C). Note that the speciation analysis was conducted by using Visual Minteq ${ }^{1}$ and the stability constants shown in Table 1 in the main text. 


\section{SI 2 Supporting modeling data}
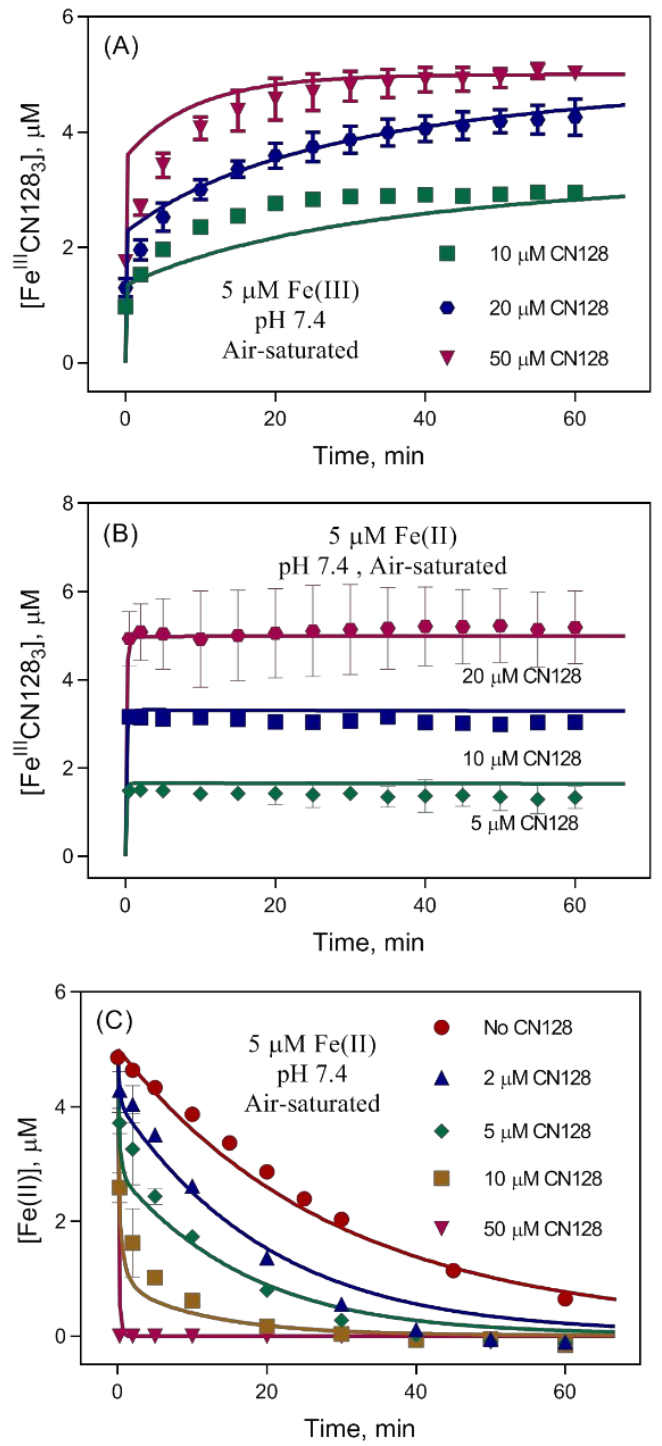

FIGURE S2. Formation of $\mathrm{Fe}^{\mathrm{III}}(\mathrm{CN} 128)_{3}$ in the presence of $5 \mu \mathrm{M} \mathrm{Fe}$ (III) (Panel A) or $5 \mu \mathrm{M} \mathrm{Fe}$ (II) (Panel B) and the CN128 catalyzed oxidation of Fe(II) (Panel C) in the presence of a range of CN128 concentrations. Error bars are standard errors from triplicate measurements. The solid lines represent the model fitting to the experimental data. 
SI 3 Definition of $\mathrm{p} K_{\mathrm{a}}$ values of CN128, deferiprone (DFP) and dopamine

Scheme S1. Acid-base equilibrium of CN128, DFP and dopamine (DA)<smiles>Cc1c(O)c(O)cc[n+]1[C@H](CO)c1ccccc1</smiles>

\section{CN128}<smiles>Cc1c(O)c(O)cc[n+]1C</smiles>

DFP<smiles>NCCc1ccc(O)c(Oc2cc(CCN)ccc2CCN)c1</smiles>

Dopamine 


\section{SI 4 Kinetic model for interaction between iron and DA}

Table S1 Modelled reactions and rate constants for the autoxidation of DA at pH 7.4.

\begin{tabular}{|c|c|c|c|}
\hline No. & Reactions & $\begin{array}{l}\text { Rate constants } \\
\left(\mathrm{M}^{-1} \mathrm{~s}^{-1} \text { or s }{ }^{-1}\right)\end{array}$ & Reference \\
\hline 1 & $\mathrm{DA}+\mathrm{O}_{2} \stackrel{k_{1}}{\longrightarrow} \mathrm{O}_{2}^{\cdot-}+\mathrm{DA}^{\bullet-}$ & $k_{1}=8.24 \times 10^{-3}$ & 1 \\
\hline \multirow{2}{*}{2} & \multirow{2}{*}{$\mathrm{DA}^{\cdot-}+\mathrm{O}_{2} \underset{k_{-2}}{\stackrel{k_{2}}{\rightleftarrows}} \mathrm{DAQ}+\mathrm{O}_{2}^{\cdot-}$} & $k_{2}=2.95 \times 10^{3}$ & 2 \\
\hline & & $k_{-2}=1.0 \times 10^{9}$ & 2 \\
\hline 3 & $\mathrm{DA}^{\bullet-}+\mathrm{DA}^{\bullet-} \stackrel{k_{3}}{\longrightarrow} \mathrm{DA}+\mathrm{DAQ}$ & $k_{3}=2.35 \times 10^{8}$ & 3 \\
\hline 4 & $\mathrm{DAQ} \stackrel{k_{4}}{\longrightarrow} \mathrm{DAL}$ & $k_{4}=4.45$ & 1 \\
\hline 5 & $\mathrm{DAL}+\mathrm{DAQ} \stackrel{k_{5}}{\longrightarrow} \mathrm{DA}+\mathrm{DAC}$ & $k_{5}=5.30 \times 10^{6}$ & 4 \\
\hline 6 & $\mathrm{DAL}+\mathrm{O}_{2} \stackrel{k_{6}}{\longrightarrow} \mathrm{DAC}+\mathrm{H}_{2} \mathrm{O}_{2}$ & $k_{6}=5.12$ & 1 \\
\hline 7 & $\mathrm{O}_{2}^{\cdot-}+\mathrm{O}_{2}^{\bullet-} \stackrel{k_{7}}{\longrightarrow} \mathrm{H}_{2} \mathrm{O}_{2}+\mathrm{O}_{2}$ & $k_{7}=1.9 \times 10^{5}$ & 5 \\
\hline 8 & $\mathrm{DA}^{\bullet-}+\mathrm{O}_{2}^{\bullet-} \stackrel{k_{8}}{\longrightarrow} \mathrm{DAQ}+\mathrm{H}_{2} \mathrm{O}_{2}$ & $k_{8}=8.27 \times 10^{9}$ & 6 \\
\hline
\end{tabular}

DA, dopamine; $\mathrm{DA}^{\bullet-}$, semiquinone radical; DAQ, dopamine-o-quinone; DAC, dopaminochrome; DAL, leukoaminochrome and $\mathrm{O}_{2}{ }^{\circ}$, , superoxide

(1) Sun, et al. ${ }^{2}$; (2) Pham and Waite ${ }^{3}$; (3) Borovansky, et al. ${ }^{4}$; (4) Land, et al. ${ }^{5}$; (5) Zafiriou ${ }^{6}$ and (6) Sun, et al. 7 . 
TABLE S2 Modelled reactions and rate constants for Fe(III)-catalyzed oxidation of DA at pH 7.4.

\begin{tabular}{|c|c|c|c|}
\hline No. & Reactions & $\begin{array}{l}\text { Rate constants } \\
\left(\mathrm{M}^{-1} \mathrm{~s}^{-1} \text { or s }{ }^{-1}\right)\end{array}$ & $\begin{array}{c}\text { Referenc } \\
\mathrm{e}\end{array}$ \\
\hline 9 & $\mathrm{Fe}(\mathrm{III})+\mathrm{Fe}(\mathrm{III})_{\mathrm{I}} \stackrel{k_{9}}{\longrightarrow} \mathrm{AFO}+\mathrm{nH}^{+}$ & $k_{9}=5.00 \times 10^{6}$ & 7 \\
\hline 10 & $>\mathrm{Fe}(\mathrm{III})_{\mathrm{n}}+\mathrm{DA} \stackrel{k_{10}}{\longrightarrow}>\mathrm{Fe}(\mathrm{III})_{\mathrm{n}-1}+\mathrm{Fe}^{\mathrm{III}} \mathrm{DA}$ & $k_{10}=2.34$ & 6 \\
\hline 11 & $>\mathrm{Fe}(\mathrm{III})_{\mathrm{n}}+\mathrm{DA} \stackrel{k_{11}}{\longrightarrow}>\mathrm{Fe}(\mathrm{III})_{\mathrm{n}-1}+\mathrm{Fe}(\mathrm{II})+\mathrm{DA}^{\bullet-}$ & $k_{11}=0.60$ & 6 \\
\hline 12 & $\mathrm{Fe}(\mathrm{III})+\mathrm{DA} \underset{k_{-12}}{\stackrel{k_{12}}{\rightleftarrows}} \mathrm{Fe}^{\mathrm{III}} \mathrm{DA}$ & $\begin{array}{l}k_{12}=4.15 \times 10^{5} \\
k_{-12}=0.46\end{array}$ & 1 \\
\hline 13 & $\mathrm{Fe}^{\mathrm{III}} \mathrm{DA}+\mathrm{DA} \underset{k_{-13}}{\stackrel{k_{13}}{\rightleftarrows}} \mathrm{Fe}^{\mathrm{III}} \mathrm{DA}_{2}$ & $\begin{array}{l}k_{13}=4.50 \times 10^{5} \\
k_{-13}=2.59 \times 10^{-4}\end{array}$ & 1 \\
\hline 14 & $\mathrm{Fe}^{\mathrm{III}} \mathrm{DA}+\mathrm{O}_{2}^{--} \stackrel{k_{14}}{\longrightarrow} \mathrm{Fe}^{\mathrm{II}} \mathrm{DA}+\mathrm{O}_{2}$ & $k_{14}=1.50 \times 10^{8}$ & 9 \\
\hline 15 & $\mathrm{Fe}^{\mathrm{III}} \mathrm{DA} \stackrel{k_{15}}{\longrightarrow} \mathrm{Fe}(\mathrm{II})+\mathrm{DA}^{\cdot-}$ & $k_{15}=0.23$ & 10 \\
\hline 16 & $\mathrm{Fe}^{\mathrm{III}} \mathrm{DA}_{2} \stackrel{k_{16}}{\longrightarrow} \mathrm{Fe}(\mathrm{II})+\mathrm{DA}+\mathrm{DA}^{\bullet-}$ & $k_{16}=7.26 \times 10^{-5}$ & 6 \\
\hline 17 & $\mathrm{Fe}(\mathrm{III})+\mathrm{O}_{2}^{\bullet-} \underset{k_{-17}}{\stackrel{k_{17}}{\rightleftarrows}} \mathrm{Fe}(\mathrm{II})+\mathrm{O}_{2}$ & $\begin{array}{l}k_{17}=1.50 \times 10^{8} \\
k_{-17}=0.77\end{array}$ & $\begin{array}{c}11 \\
6\end{array}$ \\
\hline 18 & $>\mathrm{Fe}(\mathrm{III})_{\mathrm{n}}+\mathrm{O}_{2}^{\cdot-} \stackrel{k_{18}}{\longrightarrow}>\mathrm{Fe}(\mathrm{III})_{\mathrm{n}-1}+\mathrm{Fe}(\mathrm{II})+\mathrm{O}_{2}$ & $k_{18}=3.70 \times 10^{5}$ & 6 \\
\hline
\end{tabular}

DA, dopamine; $\mathrm{DA}^{\bullet-}$, semiquinone radical; DAQ, dopamine-o-quinone; $\mathrm{O}_{2}{ }^{\bullet-}$, , superoxide; $\mathrm{Fe}(\mathrm{III})$, inorganic ferric ion; Fe(III), total inorganic Fe(III); AFO, ferrihydrite and Fe(II), inorganic ferrous ion

(7) Pham, et al. ${ }^{8}$; (8) Blesa and Matijević ${ }^{9}$; (9) Rose and Waite ${ }^{10}$; (10) El-Avaan, et al. ${ }^{11}$ and (11) Rush and Bielski ${ }^{12}$. 
TABLE S3 Modelled reactions and rate constants for Fe(II)-catalyzed oxidation of DA at pH 7.4.

\begin{tabular}{|c|c|c|c|}
\hline No. & Reactions & $\begin{array}{l}\text { Rate constants } \\
\left(\mathrm{M}^{-1} \mathrm{~s}^{-1} \text { or s }^{-1}\right)\end{array}$ & Reference \\
\hline 19 & $\mathrm{Fe}(\mathrm{II})+\mathrm{O}_{2}^{\cdot-} \stackrel{k_{19}}{\longrightarrow} \mathrm{Fe}(\mathrm{III})+\mathrm{H}_{2} \mathrm{O}_{2}$ & $k_{19}=1.00 \times 10^{7}$ & 11 \\
\hline 20 & $\mathrm{Fe}(\mathrm{II})+\mathrm{H}_{2} \mathrm{O}_{2} \stackrel{k_{20}}{\longrightarrow} \mathrm{Fe}(\mathrm{III})+\cdot \cdot \mathrm{OH}+\mathrm{OH}^{-}$ & $k_{20}=1.33 \times 10^{4}$ & 12 \\
\hline 21 & $\mathrm{Fe}(\mathrm{II})+\mathrm{DA} \underset{k_{-21}}{\stackrel{k_{21}}{\rightleftarrows}} \mathrm{Fe}^{\mathrm{II}} \mathrm{DA}$ & $\begin{array}{l}k_{21}=7.50 \times 10^{2} \\
k_{-21}=1.60 \times 10^{-3}\end{array}$ & 6 \\
\hline 22 & $\mathrm{Fe}^{\mathrm{II}} \mathrm{DA}+\mathrm{O}_{2} \stackrel{k_{22}}{\longrightarrow} \mathrm{Fe}^{\mathrm{III}} \mathrm{DA}+\mathrm{O}_{2}^{\cdot-}$ & $k_{22}=1.45 \times 10^{2}$ & 6 \\
\hline 23 & $\mathrm{Fe}^{\mathrm{II}} \mathrm{DA}+\mathrm{H}_{2} \mathrm{O}_{2} \stackrel{k_{23}}{\longrightarrow} \mathrm{Fe}^{\mathrm{III}} \mathrm{DA}+\cdot \mathrm{OH}+\mathrm{OH}^{-}$ & $k_{23}=1.33 \times 10^{4}$ & 12 \\
\hline 24 & $\mathrm{Fe}^{\mathrm{II}} \mathrm{DA}+\mathrm{O}_{2}^{\bullet-} \stackrel{k_{24}}{\longrightarrow} \mathrm{Fe}^{\mathrm{III}} \mathrm{DA}+\mathrm{H}_{2} \mathrm{O}_{2}$ & $k_{24}=1.00 \times 10^{7}$ & 9 \\
\hline 25 & $\mathrm{Fe}^{\mathrm{II}} \mathrm{DA}+\mathrm{DA}^{\bullet-} \stackrel{k_{25}}{\longrightarrow} \mathrm{Fe}^{\mathrm{III}} \mathrm{DA}+\mathrm{DA}$ & $k_{25}=1.92 \times 10^{5}$ & 6 \\
\hline
\end{tabular}

DA, dopamine; $\mathrm{DA}^{\bullet-}$, semiquinone radical; $\mathrm{O}_{2}{ }^{\bullet}$, superoxide; $\mathrm{Fe}(\mathrm{III})$, inorganic ferric ion; $\mathrm{Fe}(\mathrm{II})$, inorganic ferrous ion; $\mathrm{H}_{2} \mathrm{O}_{2}$, hydrogen peroxide and ${ }^{\circ} \mathrm{OH}$, hydroxyl radicals

(12) González-Davila, et al. ${ }^{13}$. 


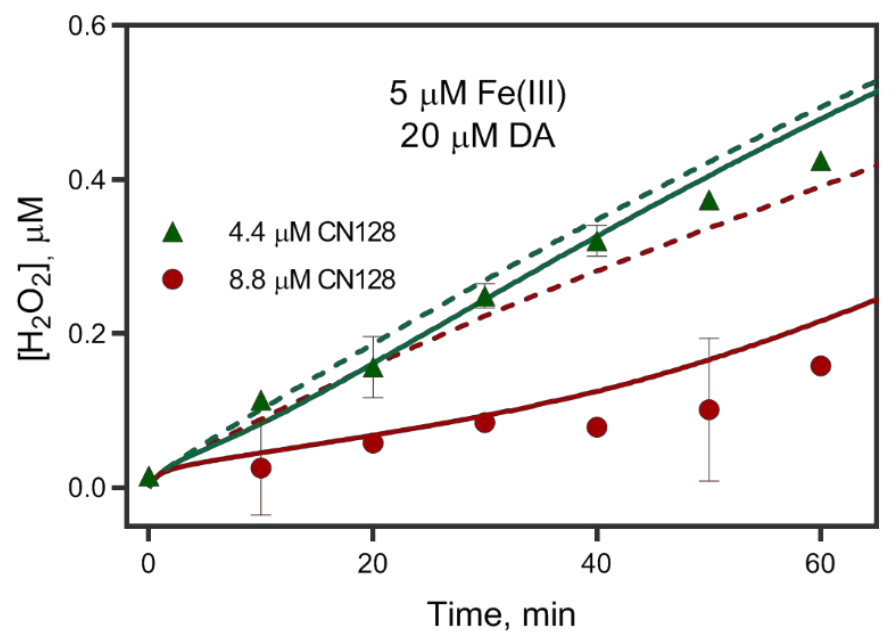

FIGURE S3. Comparison of model output with experimental data collected in the presence of $5 \mu \mathrm{M}$ $\mathrm{Fe}(\mathrm{III}), 20 \mu \mathrm{M}$ DA and 4.4 or $8.8 \mu \mathrm{M} \mathrm{CN} 128$. The solid lines represent the output for a model that includes the CN128 mediated transformation of radicals while the dashed lines represent the output for a model excluding these reactions. 


\section{SI 6 Effects of culture medium composition on the iron transformation}

The presence of a variety of culture medium constituents may influence the transformation of iron species which, in turn, may result in a discrepancy between the results collected in the simplified acellular buffer solution and the culture medium.

As can be seen from FIGURE S4A, the oxidation of Fe(II) was more rapid in the culture medium than in the acellular buffer solution in the absence of DA with almost all the iron being oxidized within the first $10 \mathrm{~min}$. The removal of $\mathrm{Fe}(\mathrm{II})$ was even more rapid in the presence of $0.2 \mathrm{mM}$ DA used in the cell toxicity study, presumably as a result of the formation of $\mathrm{Fe}^{\mathrm{II}} \mathrm{DA}$, with the rate of removal essentially too rapid to measure in both the buffer solution and the culture medium in the presence of DA (as shown in FIGURE S4A). The subsequent extent of formation of $\mathrm{Fe}^{\mathrm{III}}(\mathrm{DA})_{2}$ upon the addition of $20 \mu \mathrm{M} \mathrm{Fe}$ (II) into $0.2 \mathrm{mM}$ DA was slightly higher in the simplified acellular solution than in the culture medium (as shown in FIGURE S4B). The instantaneous formation of this complex was consistent with the rapid removal of $\mathrm{Fe}(\mathrm{II})$ from solution.

The formation of $\mathrm{Fe}^{\mathrm{III}}(\mathrm{DA})_{2}$ in the presence of $20 \mu \mathrm{M} \mathrm{Fe}(\mathrm{III})$ and $0.2 \mathrm{mM} \mathrm{DA}$ was similar to the scenario of $\mathrm{Fe}$ (II) with the concentration of DA bound iron in the simplified acellular buffer solution being higher than that in the presence of the culture medium (FIGURE S4C). The difference in the concentration of $\mathrm{Fe}^{\mathrm{III}}(\mathrm{DA})_{2}$ in these two solutions decreased over time and eventually became stable after about one hour. However, the concentration of $\mathrm{Fe}^{\mathrm{III}}(\mathrm{DA})_{2}$ formed in the presence of $\mathrm{Fe}(\mathrm{III})$ was lower than the presence of the $\mathrm{Fe}(\mathrm{II})$ salt. This phenomenon may be attributed to either the initial hydrolysis of $\mathrm{Fe}(\mathrm{III})$ or the competition between DA and any organics initially present in the culture medium. The possibility that such competition occurs is a particular consideration for the culture medium as a low concentration of Fe is (according to the manufacturer) purportedly present (as an essential nutrient) in dissolved form. The capacity of the culture medium for Fe(III) binding however was not explored further in this study.

As shown in FIGURE S4D, when the concentration of DA was high enough (1 $\mathrm{mM}$ in this instance), addition of $\mathrm{Fe}(\mathrm{III})$ into the $1 \mathrm{mM}$ DA solution resulted in very rapid formation of $\mathrm{Fe}^{\mathrm{III}}(\mathrm{DA})_{2}$ with essentially all of the added iron being bound by DA from the outset. This rapid formation Fe $\mathrm{Fe}^{\mathrm{III}}(\mathrm{DA})_{2}$ at the higher DA concentration reflects the efficacy with which DA prevented either Fe(III) hydrolysis and/or Fe(III) binding by other complexants present within the culture medium. After the initial formation of DA bound iron, the concentration of this complex is stable with the $\mathrm{Fe}^{\mathrm{III}}(\mathrm{DA})_{2}$ concentration in the culture medium approximately $1.5 \mu \mathrm{M}$ higher than that in the buffer solution. The higher concentration of $\mathrm{Fe}^{\mathrm{III}}(\mathrm{DA})_{2}$ formed in the culture medium compared to the buffer solution might be a result of either the effectiveness with which DA binds Fe(III) in this matrix or may reflect a reduced extent of oxidation of DA in this medium. 

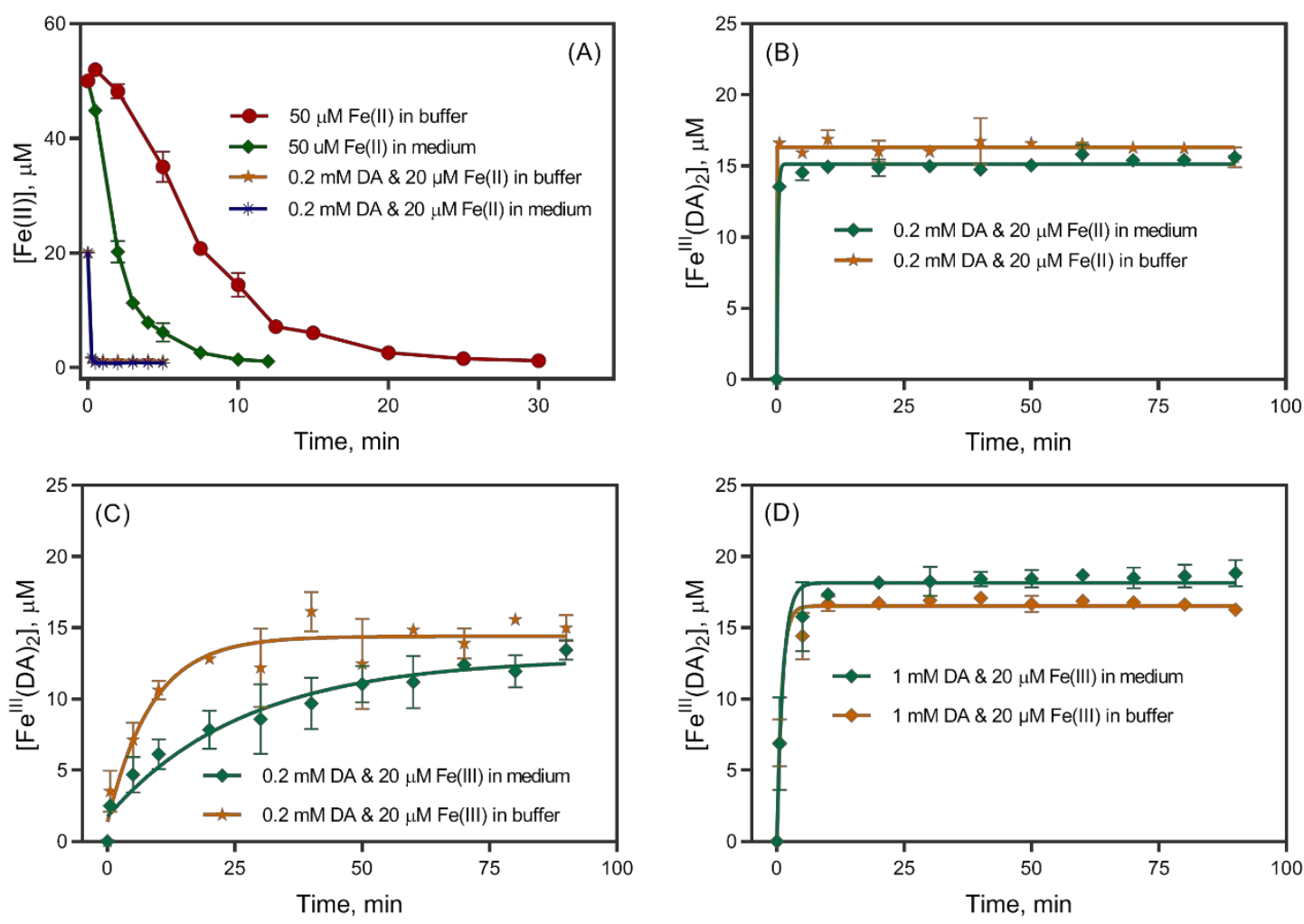

FIGURE S4. Comparison of the difference regarding the simplified acellular buffer solution and culture medium (Dulbecco's Modified Eagle's Medium/Nutrient Mixture F-12 Ham, D2906) on the oxidation of Fe(II) (Panel A), formation of Fe $\mathrm{III}^{\mathrm{II}}(\mathrm{DA})_{2}$ in the presence of $20 \mu \mathrm{M} \mathrm{Fe}$ (II) into $0.2 \mathrm{mM}$ DA (Panel B), formation of $\mathrm{Fe}^{\mathrm{III}}(\mathrm{DA})_{2}$ in the presence of $20 \mu \mathrm{M} \mathrm{Fe}$ (III) into $0.2 \mathrm{mM}$ DA (Panel C) and formation of $\mathrm{Fe}^{\mathrm{III}}(\mathrm{DA})_{2}$ in the presence of $20 \mu \mathrm{M} \mathrm{Fe}(\mathrm{III})$ into $1 \mathrm{mM}$ DA (Panel D).

Despite the small differences in behaviour of $\mathrm{Fe}(\mathrm{II})$ and $\mathrm{Fe}(\mathrm{III})$ in the culture medium and buffer, the results presented in FIGURE S4 suggest that the kinetic model that has been developed based on the results collected in buffer solution should have relevance to the behaviour of $\mathrm{Fe}(\mathrm{II})$ and $\mathrm{Fe}(\mathrm{III})$ in the culture medium. As such, the kinetic model that has been developed to describe the generation of oxidants in the buffer solution should be of value in rationalising the toxicity results shown in FIGURES 1 and 2. In the presence of DA and ferrous iron, the transformation and speciation of Fe(II) and $\mathrm{Fe}(\mathrm{III})$ was almost the same in these two media under the conditions used in this work. While a difference was observed on addition of Fe(III) to solutions containing $0.2 \mathrm{mM}$ DA, the difference was minimal after one hour. In view of the duration of the toxicity studies (6-7 hours), this initial diference in $\mathrm{Fe}(\mathrm{III})$ behaviour would be expected to have minimal impact on toxicity. 


\section{SI 7 Measurement of DA- and CN128- bound iron}

To ensure the complete formation of the $\mathrm{Fe}^{\mathrm{III}}(\mathrm{DA})_{2}$ complex, the DA and $\mathrm{Fe}(\mathrm{III})$ containing solution was prepared for at least one hour before the addition of $\mathrm{CN} 128$ with the spectrum of the mixed solution monitored over the following hour. The concentration of $\mathrm{Fe}^{\mathrm{III}}(\mathrm{DA})_{2}$ was measured at $700 \mathrm{~nm}$ (with minimal interference from $\mathrm{Fe}^{\mathrm{III}}(\mathrm{CN} 128)_{3}$ as is clear from FIGURE S5). The concentration of $\mathrm{Fe}^{\mathrm{III}}(\mathrm{CN} 128)_{3}$ was deduced from the absorbance at $460 \mathrm{~nm}$ (Eq.S2) after subtracting the absorbance of $\mathrm{Fe}^{\mathrm{III}}(\mathrm{DA})_{2}$ at this wavelength

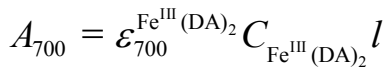

$$
\begin{aligned}
& A_{460}=\varepsilon_{460}^{\mathrm{Fe}^{\mathrm{III}}(\mathrm{DA})_{2}} C_{\mathrm{Fe}^{\mathrm{III}}(\mathrm{DA})_{2}} l+\varepsilon_{460}^{\mathrm{Fe}}{ }^{\mathrm{III}(\mathrm{CN} 128)_{3}} C_{\mathrm{Fe}^{\mathrm{III}}(\mathrm{CN} 128)_{3}} l
\end{aligned}
$$

where $A$ is the overall absorbance at a specific wavelength, $\varepsilon_{i}^{j}$ is the molar absorptivity of component $j$ at wavelength $i, C_{j}$ is the concentration of component $j$ and $l$ is length of the cuvette, which is $10 \mathrm{~cm}$ in this study. Instead of using a peak absorbance at $580 \mathrm{~nm}{ }^{14,15}$, the concentration of $\mathrm{Fe}^{\mathrm{III}}(\mathrm{DA})_{2}$ was calculated by using linear regression curves at $700 \mathrm{~nm}$ with baseline correction at $850 \mathrm{~nm}$ where the

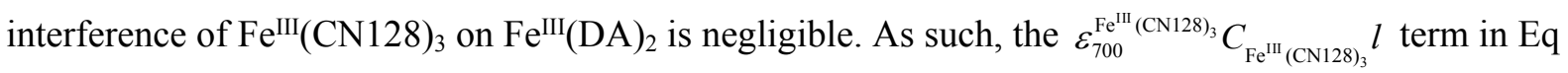
(SI1) can be omitted since the molar absorptivity of $\mathrm{Fe}^{\mathrm{III}}(\mathrm{CN} 128)_{3}$ at $700 \mathrm{~nm}$ is around 0 . Accordingly, the concentration of $\mathrm{Fe}^{\mathrm{III}}(\mathrm{CN} 128)_{3}$ in the presence of DA was calculated by using $\mathrm{Eq}(\mathrm{S} 2)$. 
SI 8 Spectrum and calibration curves of $\mathrm{Fe}^{\mathrm{III}}(\mathrm{CN} 128)_{3}$
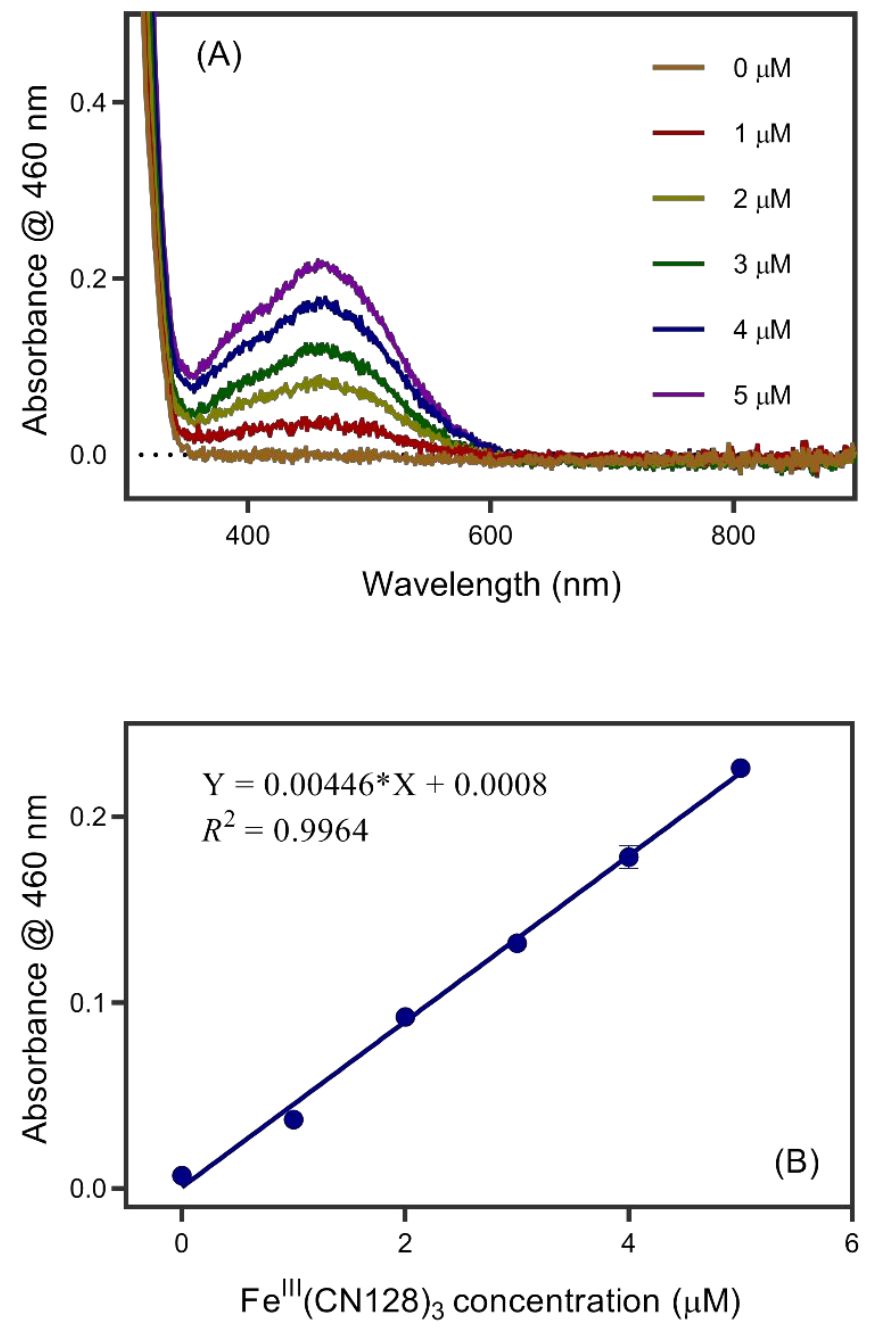

Figure S5. Measured spectrum of $\mathrm{Fe}^{\mathrm{III}}(\mathrm{CN} 128)_{3}$ (panel A) and calibration plot for $\mathrm{Fe}^{\mathrm{III}}(\mathrm{CN} 128)_{3}$ (panel B) in $0.1 \mathrm{M} \mathrm{NaCl}$ at $\mathrm{pH} 7.4$ in the presence of $500 \mu \mathrm{M} \mathrm{CN} 128$ under deoxygenated condition. 


\section{References}

1. Gustafsson, J. P., Visual MINTEQ 3.0 user guide. Dep. of Land and Water Resour. Eng., KTH Royal Inst. of Technol., Stockholm, Sweden 2005.

2. Sun, Y.; Pham, A. N.; Waite, T. D., Mechanism underlying the effectiveness of deferiprone in alleviating Parkinson's Disease symptoms. ACS Chem. Neurosci. 2018, 9, (5), 1118-1127.

3. Pham, A. N.; Waite, T. D., Cu (II)-catalyzed oxidation of dopamine in aqueous solutions: Mechanism and kinetics. J. Inorg. Biochem. 2014, 137, 74-84.

4. $\quad$ Borovansky, J.; Edge, R.; Land, E. J.; Navaratnam, S.; Pavel, S.; Ramsden, C. A.; Riley, P. A.; Smit, N. P., Mechanistic studies of melanogenesis: the influence of $N$ - substitution on dopamine quinone cyclization. Pigm. Cell Res. 2006, 19, (2), 170-178.

5. $\quad$ Land, E.; Ito, S.; Wakamatsu, K.; Riley, P., Rate constants for the first two chemical steps of eumelanogenesis. Pigm. Cell Res. 2003, 16, (5), 487-493.

6. Zafiriou, O. C., Chemistry of superoxide ion-radical $\left(\mathrm{O}_{2}^{-}\right)$in seawater. I. $\mathrm{p} K^{*}$ aswb $(\mathrm{HOO})$ and uncatalyzed dismutation kinetics studied by pulse radiolysis. Mar. Chem. 1990, 30, 31-43.

7. Sun, Y.; Pham, A. N.; Waite, T. D., Elucidation of the interplay between Fe(II), Fe(III), and dopamine with relevance to iron solubilization and reactive oxygen species generation by catecholamines. J. Neurochem. 2016, 137, (6), 955-968.

8. Pham, A. N.; Rose, A. L.; Feitz, A. J.; Waite, T. D., Kinetics of Fe(III) precipitation in aqueous solutions at $\mathrm{pH} 6.0-9.5$ and $25^{\circ} \mathrm{C}$. Geochim. Cosmochim. Acta 2006, 70, (3), 640-650.

9. Blesa, M. A.; Matijević, E., Phase transformations of iron oxides, oxohydroxides, and hydrous oxides in aqueous media. Adv. Colloid Interfac 1989, 29, (3), 173-221.

10. Rose, A. L.; Waite, T. D., Effect of dissolved natural organic matter on the kinetics of ferrous iron oxygenation in seawater. Environ. Sci. Technol. 2003, 37, (21), 4877-4886.

11. El-Avaan, U.; Herlinger, E.; Jameson, R.; Linert, W., Anaerobic oxidation of dopamine by iron(III). J. Chem. Soc., Dalton Trans. 1997, 16, 2813-2818.

12. Rush, J. D.; Bielski, B., Pulse radiolytic studies of the reactions of $\mathrm{HO}_{2} / \mathrm{O}_{2}{ }^{-}$with $\mathrm{Fe}(\mathrm{II}) / \mathrm{Fe}(\mathrm{III})$ ions. The reactivity of $\mathrm{HO}_{2} / \mathrm{O}_{2}{ }^{-}$with ferric ions and its implication on the occurrence of the HaberWeiss reaction. J. Phys. Chem. 1985, 89, (23), 5062-5066.

13. González-Davila, M.; Santana-Casiano, J. M.; Millero, F. J., Oxidation of iron (II) nanomolar with $\mathrm{H}_{2} \mathrm{O}_{2}$ in seawater. Geochim. Cosmochim. Acta 2005, 69, (1), 83-93.

14. Avdeef, A.; Sofen, S. R.; Bregante, T. L.; Raymond, K. N., Coordination chemistry of microbial iron transport compounds. 9. Stability constants for catechol models of enterobactin. J. Am. Chem. Soc. 1978, 100, (17), 5362-5370.

15. Sever, M. J.; Wilker, J. J., Visible absorption spectra of metal-catecholate and metal-tironate complexes. J. Chem. Soc., Dalton Trans. 2004, (7), 1061-1072. 